\title{
PEMBERDAYAAN MASYARAKAT DESA MUARADUA MELALUI KULIAH KERJA MAHASISWA TEMATIK
}

\author{
${ }^{1 *}$ Beni Junedi, ${ }^{2}$ Agung Prayoga, ${ }^{3}$ Kukuh Joez Rizal, ${ }^{4}$ Windi Amelia, \\ ${ }^{5}$ Ine Nurhasanah \\ Universitas Bina Bangsa, Serang, Banten, Indonesia \\ E-mail : *benijunedi07@gmail.com
}

Manuskrip: Juni -2021; Ditinjau: Juni -2021; Diterima: Juli -2021;

Online: Juli-2021; Diterbitkan: Juli-2021

\begin{abstract}
ABSTRAK
Desa Muaradua merupakan desa yang perlu menjadi perhatian terutama dalam peningkatan sumber daya manusia baik dari aspek pendidikan, ekonomi dan sosial. Hal ini disebabkan karena masih rendahnya sumber daya manusia yang ada di desa tersebut. Metode pengabdian kepada masyarakat melalui kegiatan kuliah kerja mahasiswa tematik yaitu pendidikan masyarakat dan pelatihan dilaksanakan dengan tahapan bersifat siklikal melalui tujuh tahapan: tahap persiapan, tahap pengkajian, tahap perencanaan alternatif kegiatan, tahap formulasi rencana aksi, tahap implementasi kegiatan, tahap evaluasi, dan tahap terminasi. Hasil kegiatan pengabdian kepada masyarakat terdiri dari peningkatan kesadaran masyarakat pentingnya pendidikan dalam meningkatkan taraf hidup yang lebih baik terlihat dari peningkatan perhatian orang tua untuk meningkatkan Pendidikan anak-anak desa di Muaradua. Terwujudnya masyarakat yang sadar hukum lingkungan terutama pada pembakaran hutan, penebangan hutan, serta membuang sampah di sungai, karena desa Muaradua berada di aliran sungai. Peningkatan pemasaran anyaman tikar dari daun pandan dengan cara penyuluhan cara mengemas dan memasarkan produksi secara luring dan daring tidah hanya terbatas pada wilayah kabupaten Lebak. Meningkatnya pemahaman masyarakat tentang covid 19 dan partisipasi masyarakat melakukan vaksinasi tanpa paksaan, cemas dan rasa takut. Terwujudnya lingkungan masyarakat yang bersih dan sehat melalui kegiatan Jum'at bersih. Peningkatan minat dan motivasi remaja dan pemuda menekuni seni Islam marawis karena desa Muaradua mayoritas muslim dan banyak memiliki pondok pesantren dan madrasah. Peningkatan sumber daya manusia di desa Muaradua membantu dalam peningkatan kualitas hidup masyarakat dan menjunjung tinggi visi kabupaten Lebak.
\end{abstract}

\section{Kata Kunci : Pemberdayaan Masyarakat Desa, Kuliah Kerja Mahasiswa Tematik}




\section{PENDAHULUAN}

Pemberdayaan masyarakat sebagai upaya memberikan kekuatan atau daya bagi masyarakat sehingga keluar dari permasalahan yang dihadapi (Endah, 2020). Pemberdayaan masyarakat merupakan proses memfasilitasi masyarakat sebagai upaya mengembangkan kesejahteraan melalui peningkatan pengetahuan dan keterampilan sesuai dengan kebutuhan masyarakat. Proses pemberdayaan merupakan usaha pendidikan bertujuan untuk meningkatkan kesadaran dan pemahaman masyarakat terhadap pembangunan nasional sehingga menjadi masyarakat berdaya (Putra \& Ismaniar, 2020). Pemberdayaan masyarakat merupakan suatu proses pembangunan yang mendorong inisiatif masyarakat dalam memperbaiki kondisi dan situasi yang ada dilingkungan masyarakat itu sendiri (V. Y. Utami, 2020). Memberdayakan masyarakat adalah upaya untuk meningkatkan kemampuan dan kemandiriannya (H. N. Utami et al., 2019). Pemberdayaan masyarakat merupakan upaya untuk memampukan dan memandirikan masyarakat (Wance et al., 2020).

Pemberdayaan masyarakat desa perlu menjadi perhatian terutama di Desa Muaradua Kecamatan Cikulur Kabupaten Lebak. Desa Muaradua merupakan desa yang mayoritas penduduknya petani, buruh dan pekerja harian lepas. Pada sektor ekonomi kreatif masyarakat memiliki usaha mikro kecil menengah (UMKM) akan tetapi masih bersifat tradisional dalam segi kemasan dan pemasaran. Pada sektor pendidikan masyarakat desa Muaradua perlu ditingkatkan karena masih kurangnya kesadaran orang tua terhadap peningkatan pendidikan anak. Sumber daya manusia yang ada di desa Muaradua menjadi perhatian dan perlu peningkatan melalui program-program kegiatan yang membangun. Desa Muaradua memiliki potensi sumber daya alam yang banyak akan tetapi dalam pengelolaannya belum difungsikan secara maksimal. Perlu adanya pelatihan-pelatihan yang meningkatkan keterampilan masyarakat yang pada akhirnya terjadi pemberdayaan masyarakat desa dan meningkatkan perekonomian (Isa et al., 2019).

Pada sektor kesehatan masih kurangnya pemahaman dan informasi mengenai penularan dan pencegahan virus covid 19. Masyarakat belum terbiasa menggunakan handsanityzer dan pemakaian masker dengan alas an mobilitas masyarakat tidak terlalu dinamis, masyarakat sering berkumpul dengan masyarakat lokal saja. Pada sektor lingkungan masih kurangnya kesadaran masyarakat tentang kebersihan lingkungan dan pemanfaatan sampah. Masih banyak masyarakat yang membuang sampah sembarangan baik di sungai maupun di area kebun mereka. Banyak juga masyarakat yang membakar sampah sehingga tidak memberikan nilai manfaat. Perlunya penyuluhan tentang pentingnya menjaga lingkungan dan kesadaran terhadap kebersihan lingkungan.

Pada sektor keagamaan perlu peningkatan pada kegiatan kesenian Islam yang sudah berkurang karena pengaruh modernisasi, desa Muaradua memiliki banyak Madrasah dan Pesantren. Kegiatan keseharian masyarakat desa Muaradua mengandung nilai-nilai religius baik dari kegiatan sholat berjamaan di Masjid, kegiatan wirid atau pengajian minggguan, kegiatan peringatan hari besar Islam. Akan tetapi perlu adanya peningkatan kegiatan kesenian Islam untuk melestarikan 
kesenian yang peminatnya makin berkurang. Desa Muaradua memiliki madrasah dan pondok pesantren yang dapat menunjang pelestarian budaya dan kesenian Islam yang belum berkembang dengan baik.

Beberapa hasil kegiatan pengabdian tentang pemberdayaan masyarakat; kegiatan pelatihan dan pendampingan dalam meningkatkan pemasaran via media online di E-Marketplace bagi para peserta dari Lembaga Pemberdayaan Masyarakat (LPM) (Hendra et al., 2020). Kegiatan penyuluhan dan pelatihan terhadap mitra tentang memilah sampah organik dan non organik untuk diolah agar untuk memberikan nilai ekonomis (Soeharjoto et al., 2020). Kegiatan penyuluhan pengelolaan sampah dilingkungan masyarakat Yayasan Al Kamilah menjadi bank sampah (Asep Kamaluddin Nashir, 2020). Kegiatan penyuluhan dan pendampingan tentang pengetahuan cara penularan dan pencegahan pandemic covid 19, penerapan perilaku hidup bersih dan sehat (PHBS), melaksanakan praktek membuat dan menyeprot disinfektan (Utama, 2020). Pendampingan pemberdayaan Karangtaruna dalam meningkatkan kualitas pendidikan masyarakat melalui taman belajar (Nugroho et al., 2021). Kegiatan pemberdayaan masyarakat dalam bentuk pendampingan dalam mengembangkan sistem sosial masyarakat serta potensi kesenian yang dimiliki berorientasi pada kearifan lokal (Supriyanto, 2020).

Tujuan pengabdian kepada masyarakat melalui kegiatan kuliah kerja mahasiswa tematik adalah pemberdayaan masyarakat desa Muaradua baik pada aspek pendidikan, ekonomi dan sosial dalam bentuk pendidikan masyarakat dan pelatihan.

\section{METODE}

Metode pengabdian kepada masyarakat kegiatan kuliah kerja mahasiswa (KKM) tematik berupa a) Pendidikan masyarakat melalui beberapa penyuluhan dan pendampingan, Penyuluhan dan pendampingan yang dilakukan terdiri dari 1) pemberian materi tentang seminar pendidikan di yayasan Riyadul Fatonah AlMajid, 2) pemberian materi tentang membangun masyarakat cerdas hukum dan penegakan hukum lingkungan, 3) memberikan kegiatan sosialisasi UMKM yang bertema pemberdayaan UMKM pembuatan anyaman tikar dari daun pandan, 4) Sosialisasi pencegahan Covid 19 dan pelaksanaan vaksin Covid 19, 5) sosialisasi tentang peduli kebersihan lingkungan hidup, b) pelatihan kegiatan seni Islam marawis.

Tahapan-tahapan dalam kegiatan pemberdayaan masyarakat bersifat siklikal sebagai berikut (Maulani et al., 2021).

1. Tahap persiapan

Pada tahap persiapan terdiri dari persiapan tim dan persiapan lapangan.

2. Tahap pengkajian

Tahap ini merupakan tahap mengidentifikasi masalah dan kebutuhan masyarakat.

3. Tahap perencanaan alternatif kegiatan

Tahap ini tim pengabdian secara aktif mencoba melibatkan masyarakat dalam mengatasi permasalahan. 
4. Tahap formulasi rencana aksi

Tahap ini tim pengabdian secara aktif menyusuan dan merumuskan program yang akan dilakukan.

5. Tahap Implementasi Kegiatan

Tahap ini tim pengabdian melaksanakan program yang telah direncanakan.

6. Tahap Evaluasi

Tahap ini proses pengawasan yang melibatkan tim pengabdian dan masyarakat.

7. Tahap terminasi

Tahap ini merupakan tahap perpisahan secara formal antara tim pengabdian dengan masyarakat. berikut.

Tahapan kegiatan pemberdayaan masyarakat dapat dilihat pada gambar

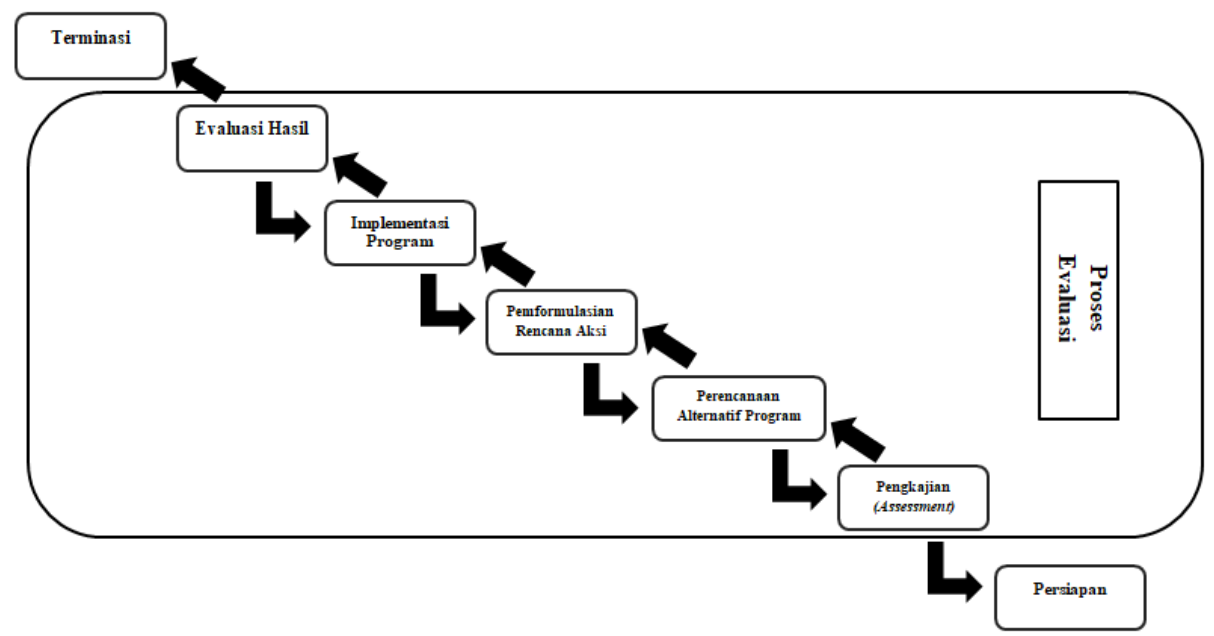

Gambar 1. Tahapan Kegiatan Pemberdayaan Masyarakat

\section{HASIL DAN PEMBAHASAN}

Desa Muaradua secara administratif terletak pada kecamatan Cikulur dengan luas wilayah 1069 Ha. Kepadatan penduduk mencapai 5.504 jiwa. Keseharian masyarakat desa Muaradua adalah bercocok tanam, bertani, buruh tani, dan berternak (kerbau, kambing, ayam, itik), perikanan, bangunan, buruh bangunan, serta berdagang dan lainnya. Jarak tempuh ke ibukota kecamatan sejauh 3 kilometer dengan waktu tempuh sekitar 10-15 menit. Pada sektor pendidikan, pendidikan formal yang ada di desa Muaradua terdapat 5 sekolah TK swasta, 5 Sekolah Dasar/Madrasah Ibtidaiyah (SD/MI) Negeri, 2 Sekolah Menengah Pertama (SMP/MTS) Negeri, 1 Sekolah Menengah Atas (SMA) Negeri, 9 Pondok Pesantren dan 5 Madrasah.

Sebagian besar penduduk desa Muaradua bekerja di sektor perkebunan dan pertanian. Hal ini didukung oleh faktor alam setempat yang terletak di pedesaan. Pola penggunaan tanah di desa Muaradua sebagian besar diperuntukan bagi warga sekitar. Sedangkan sisanya untuk tanah pertanian dan bangunan serta fasilitas umum/sosial. Mata pencaharian utama adalah sebagai petani, mata pencaharian lainnya berupa pedagang, montir, peternak dan pengrajin. 


\section{Seminar Pendidikan}

Mengadakan seminar pendidikan dengan tema "Peningkatan kompetensi guru di era pandemi covid-19 sebagai upaya mensinergikan antara sekolah dan orang tua murid". Kegiatan ini dilakukan di yayasan Riyadul Fatonah Al Majid dengan peserta dewan guru Madrasah Ibtidaiyah (MI), guru Sekolah Menengah Pertama (SMP), dan orang tua. Materi disampaikan oleh pakar pendidikan Dr. Budi Ilham Maliki S.Pd., M.M. Memberikan sebuah motivasi dan pengalaman yang baik mengenai pengetahuan umum akan pentingnya pendidikan dimasa depan dan peranan manusia dengan nilai keagamaan serta pengelolaan pendidikan yang lebih baik. Agar peningkatan kompetensi guru di era pandemi covid-19 dan pengelolaan pendidikan jarak jauh lebih baik perlu sinergi antara yayasan, kepala sekolah, dewan guru serta orang tua demi keberlanjutan pendidikan anak-anak yang ada di desa Muaradua. Kegiatan seminar Pendidikan terlihat pada gambar berikut.

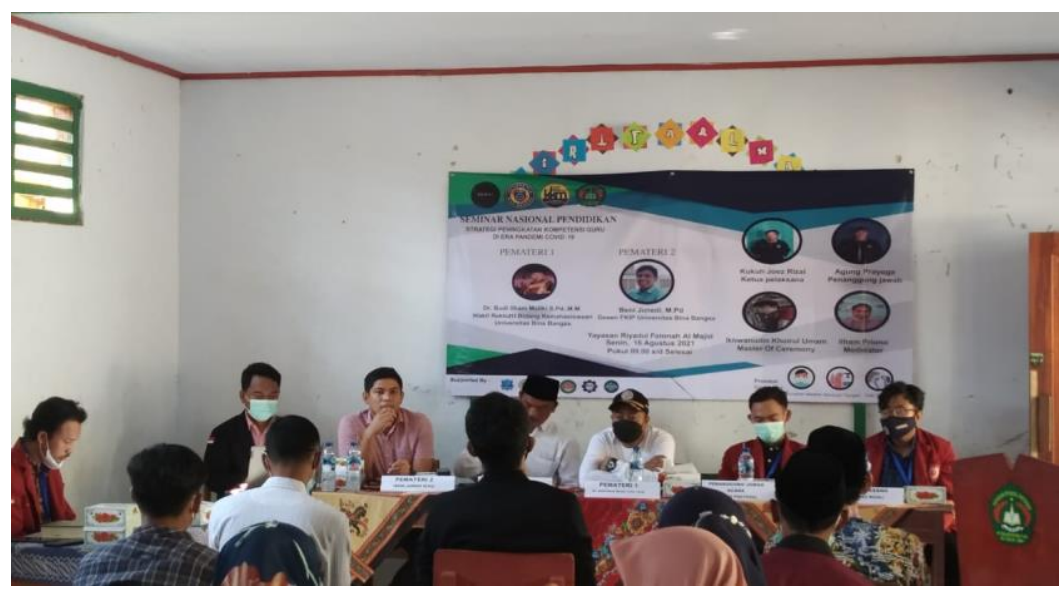

Gambar 2. Kegiatan Seminar Pendidikan

Berdasarkan gambar 2 terlihat bahwa penyampaian materi oleh pakar pendidikan yang memberikan pemahahaman kepada guru dan orang tua pentingnya pendidikan walaupun masih dalam pandemi covid-19. Disamping itu perlunya sinergi antara orang tua dan dewan guru dalam hal perhatian terhadap proses pembelajaran anak-anak di masa sekarang dan mendatang. Guru dan orang tua memiliki peran yang sama penting dalam keberlanjutan pendidikan anak-anak yang ada di desa Muaradua. Kegiatan ini dilakukan bertujuan untuk meningkatkan kualitas dan perbaikan sumber daya manusia dengan cara pemberian pemahaman kepada orang tua terhadap pentingnya sekolah dan pendidikan yang lebih tinggi demi masa depan yang lebih baik. Kegiatan ini berjalan lancar dan interaktif melalui tanya jawab baik dari guru maupun orang tua siswa. Kegiatan seminar pendidikan ditindaklanjuti dengan pemberian bimbingan belajar baik di sekolah maupun di posko KKM tematik yang dibimbing oleh mahasiswa yang berlatarbelakang dari keguruan. 


\section{Penyuluhan kesadaran hukum lingkungan}

Mengadakan seminar penyuluhan hukum yang bertema "Membangun masyarakat cerdas hukum dan penegakan hukum lingkungan". Kegiatan ini bertujuan untuk mewujudkan kesadaran hukum masyarakat, anggota masyarakat dan aparat desa menyadari dan menghayati hak dan kewajiban serta mewujudkan budaya hukum dalam sikap dan perilaku yang sadar, patuh dan taat kepada hukum demi tegaknya supremasi hukum serta terbentuknya desa sadar hukum. Kegiatan penyuluhan hukum ini dilaksanakannya di kantor PGRI Kecamatan Cikulur, kegiatan berjalan dengan baik dan lancar serta mendapat respon baik dari peserta dan masyarakat terlihat dari kegiatan tanya jawab. Kegiatan penyuluhan hukum terlihat pada gambar berikut.

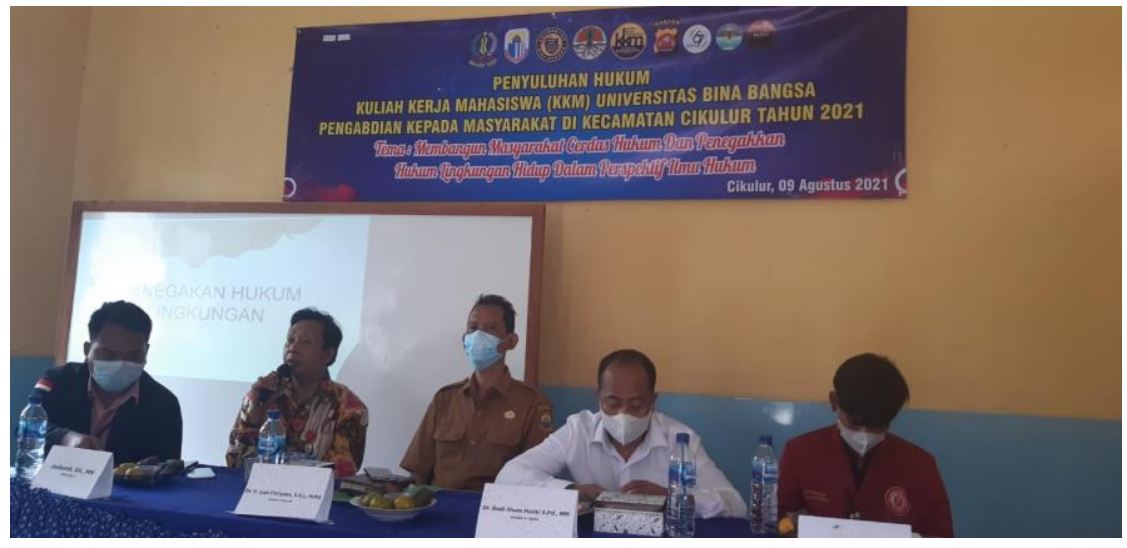

Gambar 3. Penyuluhan Kesadaran Hukum

Berdasarkan gambar 3 di atas terlihat bahwa kegiatan penyuluhan kesadaran hukum berjalan lancar. Penyuluhan kesadaran hukum ini bertujuan untuk memberikan pemahaman kepada masyarakat tentang pentingnya kesadaran hukum lingkungan, menjaga lingkungan dari bencana alam seperti banjir, longsor dan kebakaran hutan. Kegiatan penyuluhan hukum lingkungan ini dilakukan bertujuan untuk melestarikan lingkungan hidup yang bersih dan menciptakan masyarakat yang sadar akan hukum lingkungan. Kegiatan penyuluhan ini sebagai salah satu bentuk mendukung misi Kabupaten Lebak yaitu meningkatkan kualitas lingkungan hidup.

\section{Penyuluhan, pendamping UMKM, dan ekonomi kreatif}

Memberikan kegiatan penyuluhan dan pendampingan UMKM yang bertema "Pemberdayaan UMKM dan strategi pemasaran anyaman tikar dari daun pandan dan budidaya jamur". Memberikan pemahaman kepada masyarakat bahwa potensi di desa sangatlah berlimpah dan para perlu pelaku usaha mampu mengembangkan UMKM. Kegiatan ini bertujuan untuk agar hasil bumi di desa bisa dimanfaatkan dengan baik untuk kesejahteraan masyarakat dibidang ekonomi. Dengan demikian harapan masyarakat dengan adanya UMKM diharapkan akan membantu 
perekonomian masyarakat desa Muaradua. Berikut kegiatan penyuluhan dan pendampingan UMKM.

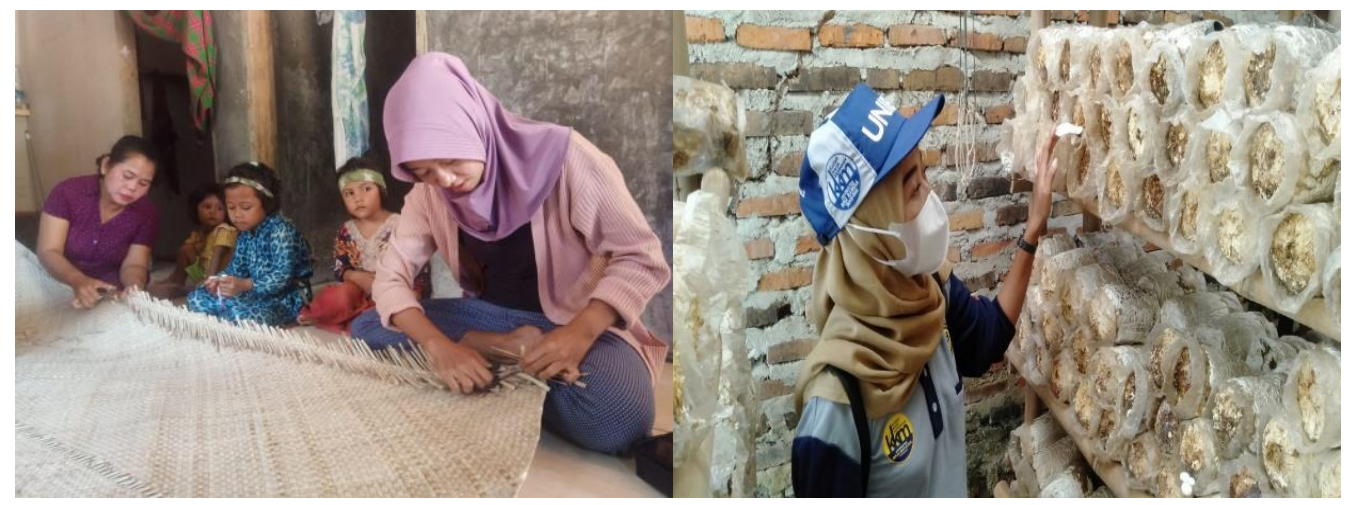

Gambar 4. Kegiatan Penyuluhan Dan Pendampingan UMKM

\section{Sosialisasi pencegahan dan pelaksanaan vaksin Covid - 19}

Covid-19 yang sedang mewabah ini memang sangat meresahkan seluruh dunia. Maka dari itu perlu sosialisasi pencegahan dan penularan Covid-19 dengan cara mencuci tangan yang baik dan benar, menggunakan handsanitizer di setiap kegiatan dan menjaga jarak, menghindari kerumunan pada setiap kegiatan. Sosialisasi ini bertujuan untuk meningkatkan kesadaran masyarakat agar terbiasa mencuci tangan dan menggunakan Handsanitizer pada saat beraktivitas kegiatan apapun dan terbiasa menjaga jarak, dan mengindari kerumunan pada saat beraktivitas atau berkegiatan. Kegiatan sosialisasi juga bertujuan untuk memberikan pemahaman kepada masyarakat pentingnya kegiatan vaksinasi sehingga masyarakat tidak perlu cemas, takut, masyarakat dapat hidup sehat dan dapat membentengi diri dari penularan virus Covid-19. Setalah dilakukan sosialisasi kelompok kuliah kerja mahasiswa tematik membantu kegiatan vaksinasi covid-19 yang berkerjasama dengan tim Kesehatan Pusat Kesehatan Masyarakat (PUSKESMAS) Kecamatan Cikulur. Berikut kegiatan sosialisasi dan vaksinasi.

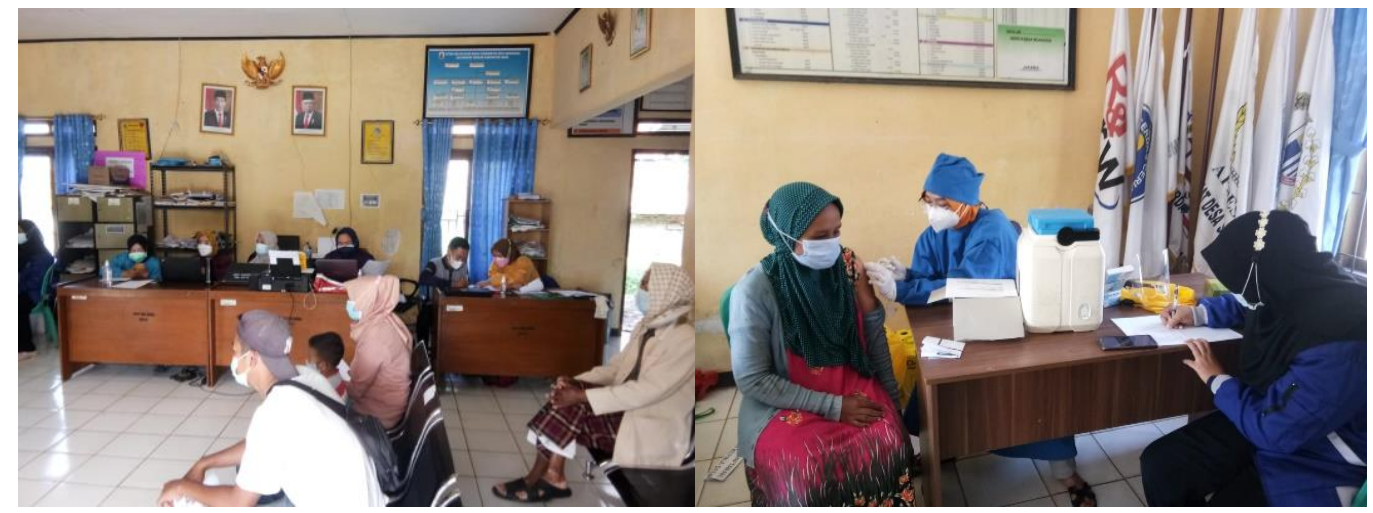

Gambar 5. Kegiatan Sosialisasi Dan Vaksinasi Covid-19 
Dalam mencegah penularan virus Covid-19 kelompok KKM bekerjasama dengan Pemerintah desa (Pemdes) Muaradua melakukan penyemprotan disinfektan di sejumlah rumah warga khususnya kampung Cibogo, kegiatan ini turut mengundang perwakilan Polsek Cikulur. Kegiatan ini bertujuan untuk sterilisasi dan pencegahan penularan Covid-19 di desa Muaradua.

\section{Sosialisasi dan pendampingan kebersihan lingkungan hidup.}

Demi menjaga kebersihan lingkungan hidup kelompok KKM tematik berkerja sama dengan pemuda desa Muaradua melakukan kegiatan sosialisasi dan pendampingan lingkungan hidup dengan melakukan kegiatan Jum'at bersih, pengadaan tempat sampah untuk fasilitas umum seperti Mesjid, Mushola, dan sekolah. Kegiatan ini bertujuan untuk memberikan edukasi terkait kesadaran kebersihan lingkungan dan pemberdayaan masyarakat kampung Cikalung dengan memfasilitasi warga berupa tempat sampah dan bank sampah. Hasil kegiatan ini menjadikan desa Muaradua bersih, nyaman dan asri dan membiasakan masyarakat untuk membuang sampah pada tempatnya. Berikut kegiatan pendampingan kebersihan lingkungan hidup.

\section{Pemanfaatan sampah plastik sebagai media tanam hidroponik}

Kurangnya kesadaran masyarakat akan pentingnya pemanfaatan sampah plastik sebagai media tanam. Kegiatan ini bertujuan untuk memberikan pemahaman kepada masyarakat tentang pemanfaatan sumber daya alam sekitar dan pengolahannya dengan menggunakan metode hidroponik. Memberikan edukasi kepada masyarakat kampung Cikalung agar lebih peduli terhadap lingkungan dengan memanfaatkan sampah botol plastik untuk dijadikan pot/wadah tanaman hidroponik. Kegiatan ini terlaksana dengan harapan supaya masyarakat lebih peka terhadap bahaya limbah plastik dan dapat memanfaatkan peluang yg ada supaya mengurangi sampah plastik. Pembuatan media tanam hidroponik dari botol bekas juga dapat memanfaatkan lahan sempit. Memberikan solusi pertanian dengan lahan sempit dan juga solusi mengurangi limbah botol plastik. Limbah botol plastik menjadi berkurang dan masyarakat dapat menikmati hasil dari media tanam hidroponik tersebut. Berikut kegiatan pemanfaatan sampah plastik.

\section{Pelatihan Seni Islam Marawis}

Desa Muaradua bernuansa religius, banyak kegiatan keagamaan yang rutinitas dilakukan warga. Kegiatan keagamaan ini bertujuan untuk meningkatkan ketakwaan dan menambah wawasan, dan pengetahuan dan memperdalam ilmu keagamaan serta meningkatkan nilai-nilai keagamaan dan keimanan sesama umat Islam. Menanamkan pengetahuan dalam segi metode membaca dan menulis Al Quran dan memahami maknanya. Agar dalam membaca dan Menulis Al Quran jauh lebih baik serta memahami kandungan dari makna Al - Quran.

Selain perpartisipasi pada kegiatan keagamaan kelompok KKM tematik juga memberikan keterampilan pelatihan seni Islam marawis di pusatkan pada Yayasan Riyadul Fatonah Al-Majid. Hal ini bertujuan untuk meningkatkan motivasi dan 
keterampilan bagi pemuda dan anak-anak kampung Cikalung Desa Muaradua. Hasil dari pelatihan ini adalah pemuda dan anak-anak Cikalung tampil pada Peringatan Hari Besar Islam 1 Muharram 1443 H berupa marawis keliling dan pawai obor. Kegiatan ini berjalan dengan lancar dan antusias di ikuti oleh pemuda, anak-anak dan pemuka masyarakat yang ada di Cikalung Desa Muaradua. Berikut kegiatan marawis dan pawai obor keliling.

\section{KESIMPULAN}

Hasil kegiatan pengabdian kepada masyarakat terdiri dari peningkatan kesadaran masyarakat pentingnya pendidikan terlihat dari peningkatan perhatian orang tua untuk meningkatkan pendidikan anak-anak desa di Muaradua melalui sinergi guru dan orang tua. Terwujudnya masyarakat yang sadar hukum lingkungan terutama pada pencegahan kebiasaan membuang sampah sembarangan, membuang sampah di sungai. Peningkatan pemasaran anyaman tikar dari daun pandan dengan cara penyuluhan cara mengemas dan memasarkan produksi secara luring dan daring tidah hanya terbatas pada wilayah kabupaten Lebak. Meningkatnya pemahaman serta partisipasi masyarakat melakukan vaksinasi tanpa paksaan, cemas dan rasa takut dalam rangka pencegahan penularan covid-19. Terwujudnya lingkungan masyarakat yang bersih dan sehat melalui kegiatan Jum'at bersih serta tumbuhnya kesadaran membuang sampah pada tempat-tempat sampah yang telah disediakan. Pemahaman masyarakat terhadap penggunaan dan pemanfaatan limbah sampah botol plastik bertambah. Peningkatan minat dan motivasi remaja, pemuda dan anakanak dalam menekuni seni Islam marawis dan pawai obor keliling dalam rangka memperingati Hari Besar Islam 1 Muharram $1443 \mathrm{H}$.

\section{SARAN}

Pemberdayaan masyarakat desa perlu ditingkatkan pada aspek yang lebih luas sehingga dapat mewujudkan masyarakat Indonesia yang maju dari segala aspek dan mampu mengejar segala bentuk ketertiggalan. Dalam kegiatan pengabdian kepada masyarakat berikutnya perlu menjadi perhatian sasaran dari kegiatan pemberdayaan lebih terfokus dan terarah kepada kemajuan sains dan teknologi pada bidang pertanian, perkebunan dan industry rumah tangga, sehingga masyarakat desa mampu mengejar segala bentuk ketertinggalan.

\section{UCAPAN TERIMA KASIH}

Penulis mengucapkan terima kasih kepada Lembaga Penelitian dan Pengabdian (LP2M) Universitas Bina Bangsa yang telah memfasilitasi kegiatan Kuliah Kerja Mahasiswa Tematik, Kepala Desa Muaradua Kecamatan Cikulur yang telah bersinergi dalam kegiatan KKM Tematik ini, terkhusus kepada pemuka masyarakat, pemuda, guru dan siswa, serta seluruh masyarakat desa Muaradua.

\section{DAFTAR PUSTAKA}

Asep Kamaluddin Nashir, Y. H. dan D. M. (2020). IPTEKS Bagi Masyarakat (IbM) Pemberdayaan Masyarakat Dalam Pengelolaan BANK Sampah Plastik di 
Lingkungan Yayasan Al Kamilah Serua Depok. Abdimas Unwahas, 5(1), 6065.

Endah, K. (2020). Pemberdayaan Masyarakat: Menggali Potensi Lokal Desa. Moderat: Jurnal Ilmiah Ilmu Pemerintahan, 6(1), 135-143.

Hendra, D., Merati, A., Aprilliani, S., Afandi, M. F., \& Nardiono, N. (2020). Perancangan Dan Penerapan E-Marketplace Untuk Usaha Kecil Dan Menengah Pada Lembaga Pemberdayaan Masyarakat Kelurahan Depok Jaya. Dedikasi Pkm, 1(1), 60. https://doi.org/10.32493/dedikasipkm.v1i1.6056

Isa, I. G. T., Setiawan, I. R., \& Jhoansyah, D. (2019). Potensi Industri "Keripik Enye" Dalam Peningkatan Kesejahteraan Masyarakat Desa Waluran Kabupaten Sukabumi. Jurnal Masyarakat Mandiri, 3(1), 29-40.

Maulani, E., Suci, N. A., Hamdani, I., Sodikin, \& Yusup, R. M. (2021). Peran Pemerintah Kelurahan Dalam Pelaksanaan Pemberdayaan Masyarakat Pada Bidang Kesehatan Di Kelurahan Cijawura Kota Bandung. Jurnal Identitas, 1(1), 1-10.

Nugroho, A., Sari, I. P., \& Putra, M. R. E. (2021). Pemberdayaan Karang Taruna dalam Meningkatkan Kualitas Pendidikan Masyarakat Melalui Taman Belajar di Desa Air Putih Kali Bandung Kecamatan Selumpung Rejang Kabupaten Rejang Lebong. Jurnal PKM Linggau, 1(1), 9-16.

Putra, W. T., \& Ismaniar. (2020). Pemberdayaan Masyarakat Melalui Pengelolaan Sampah di Bank Sampah. Jambura Journal of Community Empowerment (JJCE), 1(2), 1-10.

Soeharjoto, S., Lutfi, M. Y., \& Tajib, E. (2020). Pemberdayaan Masyarakat Melalui Pengenalan Usaha Kreatif Di Daerah Aliran Sungai Citarum Desa Mulyasari. Jurnal Penelitian Dan Pengabdian Kepada Masyarakat UNSIQ, 7(3), 219224. https://doi.org/10.32699/ppkm.v7i3.1007

Supriyanto, S. (2020). Inovasi Dan Pemberdayaan Masyarakat Melalui Kesenian Di Desa Kedu Kecamatan Kedu Kabupaten Temanggung. Abdi Seni, 10(2), 83-100. https://doi.org/10.33153/abdiseni.v10i2.3039

Utama, M. D. (2020). Produk Edukasi Cegah Covid-19 Hasil Kkn Pkm Daring Ukim Di 3 Kabupaten/Kota Di Maluku. MAREN: Jurnal Pengabdian Dan Pemberdayaan $1(2)$, 163-178. http://ejurnal.ukim.ac.id/index.php/maren/article/view/515

Utami, H. N., Sandra, \& Ruhana, I. (2019). Pemberdayaan Masyarakat dengan Pendekatan Triple Helix untuk Pengembangan Kompetensi Wirausaha Masyarakat Desa Mandiri Energi. Jurnal Ilmiah Administrasi Publik (JIAP), 5(3), 294-302.

Utami, V. Y. (2020). Dinamika Modal Sosial Dalam Pemberdayaan Masyarakat Pada Desa Wisata Halal Setanggor: Kepercayaan, Jaringan Sosial Dan Norma. Reformasi, 10(1), 34-44. https://doi.org/10.33366/rfr.v10i1.1604

Wance, M., Kaliky, P. I., \& Syahidah, U. (2020). Pkm Inovasi Pemberdayaan Masyarakat Dalam Perencanaan Pembangunan Desa Pasir Putih Kabupaten Halmahera Selatan. SELAPARANG Jurnal Pengabdian Masyarakat Berkemajuan, 3(2), 233. https://doi.org/10.31764/jpmb.v3i2.1771 